\title{
Job Stress of Academia and its Effect on their Performance in Public Sector Universities of Punjab
}

\author{
Muhammad Asif Chuadhry* \\ Hamid Khan Niazi**
}

\begin{abstract}
The study was aimed to examine the job stress of academia and its effects on their performance in public sector universities of Punjab. The objectives were to identify the nature of job stress, factors responsible for job stress, and relationship between job stress and performance of academia. There were nine regions in the Punjab. Seven universities representing each region were the population of the study. These universities were, PU from Lahore, BZU from Multan, PMAS-Arid from Rawalpindi, UOS form Sargodha, UOG from Gujrat, IUB from Bahawalpur and GCU from Faisalabad. Stratified random sampling techniques were used and strata were made with respect to the population of the study. A sample of 373 academic heads, 434 academia and 1008 students were taken for study. It was concluded from the results that academia stress is multiple factor construct, and these entire factors associated with each other's. It is also found from academia job stress negatively effect on their performance. It was recommended from results that university as an organization may conduct need assessment program for academia to explore the causes of their stress and dissatisfaction.
\end{abstract}

Keywords: Stress, job stress, academia, performance, public sector university

\footnotetext{
${ }^{*}$ PhD Scholar, Department of EPPSL, AIOU, Islamabad and Lecturer Education Preston University,Email:asif.epm@gmail.com

${ }^{* *}$ Professor of Education, Preston University, Islamabad
} 


\section{Introduction}

Job stress is one of the most important workplace health risks for employees in developed and developing countries (Paul, 2002; Danna and Griffin, 2002). Stress concerns interpersonal relationships at work, such as conflicts with the behavior of supervisors, conflicts with colleagues, conflicts with subordinates and conflicts with management policies (Paul, 2002). Job stress is increasingly becoming an epidemic in the work environment.

University academia are supposed to be responsible to produce quality graduates fit for the job market (Raza, Majid, et al, 2010) and they can better perform their job if they are exposed to formal development initiatives taken for enhancing their methodical skills (Raza and Ahmadi, 2007). Academia refers to term as "a teacher or scholar in a university or other institute of higher education" as described by the oxford dictionary. Professional development is a continuous process and involves teachers, departments and the university (Ali, 2008). Drawing upon disciplines such as anthropology, sociology, and psychology (Borko, 2004) and going "beyond the enhancement of teaching".

This research is identifying different factors of stress which are directly or indirectly affecting performance of academia in public sector universities of Punjab. In the society and educational system roles of academia and behavior of academia are continuously evolving. The role of a competent academia is to transmit knowledge, culture, skills and improve the performance of students.

As per HEC report (2007) the university faculty performs following responsibilities, while working in their respective institution as: 
Table 1

University Academia Responsibilities

\begin{tabular}{|c|c|c|}
\hline $\begin{array}{l}\text { Research and } \\
\text { Development }\end{array}$ & Teaching Activities & $\begin{array}{c}\text { Teaching } \\
\text { Development }\end{array}$ \\
\hline $\begin{array}{l}\text {.Participation in } \\
\text { academic } \\
\text { conference } \\
\text {.Participation in } \\
\text { evaluation team } \\
\text {.Research paper } \\
\text { publication } \\
\text {.Administrative } \\
\text { activities related to } \\
\text { research. } \\
\text {.Organization, editing } \\
\text { of research journal and } \\
\text { collection of articles } \\
\text {.Organization of } \\
\text { conference } \\
\text {.Applying for research } \\
\text { and development } \\
\text { funding }\end{array}$ & $\begin{array}{l}\text {.Classroom teaching } \\
\text {.Consultation of } \\
\text { students } \\
\text {.Advising of students } \\
\text {.Research supervision } \\
\text { of students (Master, } \\
\text { M.Phil, Ph.D ) } \\
\text {.Student assessment } \\
\text {.Administration of } \\
\text { entrance examination } \\
\text {.Practical learning } \\
\text { reports }\end{array}$ & $\begin{array}{l}\text { Preparation for } \\
\text { classes } \\
\text {.Creation of study } \\
\text { and teaching aids } \\
\text {.Syllabus and } \\
\text { curriculum design } \\
\text {.Member of } \\
\text { academic decision } \\
\text { body } \\
\text {.Participation in the } \\
\text { work of academic } \\
\text { and administrative } \\
\text { bodies and } \\
\text { committees outsides } \\
\text { the university. }\end{array}$ \\
\hline
\end{tabular}

The above table describe that Teaching, as a profession involve a complex work environment, leading too much of stress. The job of academia is both demanding and challenging. University Job is entirely different and more demanding than other teacher as it is much concern with classroom, office work and research. Like all other professionals, academia is also overwhelmed by multiple and complex challenges on their work place. In many parts of the world, academia is rarely provided with the resources they need to meet the high demands and expectations placed on them. The long hours at work (as they supervise students' projects, evaluate students' work, prepare lessons and conduct the examination) and their own research publication for their promotion, coupled with pressures of their job environments eventually lead to debilitating health problems (Daniel, 2003). Furthermore, the problems and hazards of society and particularly education and system are 
aggravating factors that may cause, and as a consequence, academia may prone to experience stress.

\section{Concept of Stress}

As per lay person's perspective, stress can be described as feeling worried, anxious and tense. Scientifically these feelings are manifestations of the stress experienced an intriguingly complex programmed response to the perceived threat that can have both positive and negative results. There is general consensus however, that stress is a physical, mental or emotional reaction resulting from an individual's response to environmental tensions, conflicts, pressures and similar stimuli. As commonly understood, stress is a pattern of disruptive, physiological and psychological reactions to events that threaten a person's ability to cope (Kotteeswari \& Tameem, 2014).

The concept of job stress is often confused with challenges, but these concepts are not the same challenges energized us psychology and physically, and it motivates us to learn new skills and master our jobs. When a challenge is met, we feel relaxed and satisfied thus, challenge is an important ingredient for healthy and productive work. The important of challenges in our work lives is probably what people are referring to when they say "a little bit of stress is good for you" (Mohanty, 2000; Judeh, 2011).

It may be concluded from above discussion that, stress can mean different things to different people. Stress can cause negative effect on some individual and threatening to them, while it can add excitement and challenges to others lives. There is constant interplay between the person and the environment, which is mediated by a complex set of ongoing cognitive processes that causes stress.

\section{University Academia Stress}

Stress is a part and reflects a process of interaction between individual and his workplace. Much of the early writing on stress in general had led to a proliferation of different type of definition. It was thus not surprising that when writers tried to develop a definition of job stress in general, or of "academia stress" in particular, this same proliferation would occur (Mirella, 2005).

University faculty plays a vital role in the improvement and development of knowledge and innovations, in additions to education and training. Rapidly evolving educational practices in our country affect 
educational process and teacher has to respond to both the demand of knowledge as well as the needs of the society meaningfully. Understanding and coping with the new trends in the educational system. Moreover, the increase in the body of knowledge in each discipline poses an important challenge on how to encapsulate such enhanced knowledge in a meaningful manner. A teacher has to find the right type of knowledge mix to cater the needs of the students. The pressures related to human life are cropping up day by day, society is changing abruptly the life style, modes ,ways, relationship, and other psychological variable that have increasing effected teaching profession at University level, consequently teaching becomes a profession with complex work environments that leads to occupational role stressful (Varma, 2008).

We all experience stress in our daily life, whatever type of professionals we are. Work is experienced stressful when individual feel, that they are not capable to manage it. The experience of stress is a result of an interaction between individuals' workplace, characteristics and their perception about work. The circumstances that cause stress are called stressors. Stressors vary in situation and duration. Some events are stressful for every individual but in other situation, individuals may respond differently to the same event. A stressor for one individual may not be stressor for other as it varies from situation to situation and person to person. Cresswell (2003) described the following factor of job stress as:

i. Factors intrinsic to the job

ii. Relationship at work

iii. Career development

iv. Organizational structure and climate

v. Work- home interface

On the other hand, Robbins (2004) identified the following as causes of stress at work:

i. Overload of office and home work

ii. Couple internal conflict or between parents and children conflict

iii. Restructuring of family roles through time

iv. Role captivity where they are bound by one role, but would prefer another

v. One aspect of home life that may help exacerbate pressure is that of being part of. 
It is concluded from the above discussion of literature review that following factors lead toward the stress as: autonomy of work, quality of work, flexibility of work, organization behavior, personal space, official furniture, financial benefits, individual control, energy darin and provision of privacy. These factors also contribute toward the performance of the academia.

University in the $21^{\text {st }}$ century, become very crucial to supporting the rapid developments of individuals and in local communities, societies, and internal relations and are expected to perform a wide range of new structural, social, political, cultural and educational functions (Calin, 2006). In this regards, academia requires skill and competence to fulfill these responsibilities as: Curriculum developer, Pre-service teacher, action researcher, team leader, decision maker and member of decision and policy making of university (Borko, 2004).

Academia need to update with skill, competence and new technologies to perform all task associated with their job. This is common phenomena that teacher is the key element of education. (Radcliff \& Laster, 2003).

Goswami (2015) found in his study that occupational stress brings about subjective effects such as fright, rage and apprehensions among employees resultantly poor mental and psychological health was observed.

Since last two decades, policy-makers, educational manager and universities have implemented numerous initiatives to improve the performance of their academia. There is great demand of research on university academia for their own improvement and institutes effectiveness. Especially academia role in classroom, research, curriculum development need a specific training to be more effective in all these aspects.

Thus academia perform a wide range of role in university. These relate to teaching, management, curriculum change, research and community services. All these suggest that the conception of research and policy initiatives on teacher education and development should be broadened to cover a wide range of changing teacher roles in a complex context if we are to maximize teacher effectiveness. In other words, we need to pursue a new knowledge base for university academia education and development in the new century. 


\section{Objectives of the Study}

The study addressed the following objectives:

1. Analyze factors responsible for job stress in academia in public sectors universities.

2. Identify the nature job stress of academia in public sector universities.

3. Explore a relationship between job stress and performance of academia in public sector universities.

\section{Methodology}

In this study a survey was conducted in the universities of Punjab. For this purpose three separate questionnaires were used for different categories of the sample i.e academic heads, academia and students. The data were collected through mail and research assistant where possible.

\section{Sampling Techniques}

According to Gay $(2009, \mathrm{pp} .125)$ "stratified random sampling is way to guarantee desired representation of the relevant subgroup within the sample. In the present study stratified random sampling techniques were used. There are nine regions in the province of Punjab, one university was taken from each region. These regions are Lahore, Bahawalpur, Dera Ghazi Khan, Faisalabad, Gujranwala, Multan, Sahiwal and Sargodha. Two out of nine regions i.e. Sahiwal and Dera Ghazi Khan have no public sector university. The detail of the sample drawn fort his paper is presented in table 2. 
Table 2

The Sampling Framework of the Population

\begin{tabular}{|c|c|c|c|c|c|c|c|c|}
\hline \multirow[b]{3}{*}{ 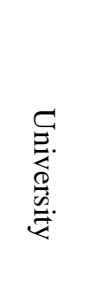 } & \multicolumn{4}{|c|}{ Academia Heads } & \multirow{2}{*}{\multicolumn{2}{|c|}{ Academia }} & \multicolumn{2}{|c|}{ Students } \\
\hline & Dean & & & & & & & \\
\hline & 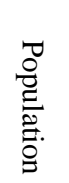 & $\frac{\mathscr{O}}{\stackrel{0}{0}}$ & 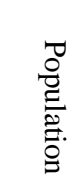 & $\begin{array}{l}\mathscr{E} \\
\stackrel{\Xi}{0} \\
\frac{0}{0}\end{array}$ & 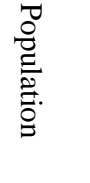 & $\begin{array}{l}\tilde{\tilde{O}} \\
\frac{\tilde{E}}{\tilde{\sigma}}\end{array}$ & 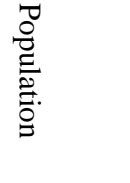 & $\begin{array}{l}\tilde{\tilde{O}} \\
\frac{\tilde{0}}{0} \\
\frac{0}{0}\end{array}$ \\
\hline $\mathrm{BZU}$ & 8 & 8 & 43 & 43 & 622 & 62 & 18,000 & 180 \\
\hline IUB & 7 & 7 & 44 & 44 & 454 & 45 & 9,000 & 90 \\
\hline GCUF & 4 & 4 & 55 & 55 & 708 & 71 & 13,000 & 130 \\
\hline PU & 13 & 13 & 113 & 113 & 1109 & 111 & 24,000 & 240 \\
\hline UOS & 8 & 8 & 33 & 33 & 654 & 65 & 14,000 & 140 \\
\hline UOG & 7 & 7 & 34 & 34 & 518 & 52 & 14,000 & 140 \\
\hline $\begin{array}{l}\text { PMAS- } \\
\text { Arid }\end{array}$ & 7 & 7 & 29 & 29 & 279 & 28 & 8,800 & 88 \\
\hline Total & 54 & 54 & 319 & 319 & 4344 & 434 & 101,800 & 1008 \\
\hline G. T & & 37 & & & 4344 & 434 & 100,800 & 1008 \\
\hline
\end{tabular}

Source: http://hed.Punjab.gov.pk/public_universities

\section{Instrumentation}

Three seprate questionnaires were used to collect data from the participants, one for academic heads (Dean, Chair), one for academia and one for students. In academia heads and academia questionnaires sixteen job stress indicators(social interaction at work, financial benefits, provision of privacy, autonomy of work, quality of work, flexibility of work, organizational behavior, working condition, official furniture, equipment facility, space organization, personal space, individual control, information over load and energy drain) were taken to analyze the stress. Furthermore, these indicators have their sub items different for both academia and their heads. Meanwhile, in student questionnaire were comprised the following items to cross check the academia levels. The items were (attitude/behavior, motivation, teaching styles, campus environment, creativity, research, grades, personal characteristics, class room participation and subject mastery of academia).

As far as data collection is concerned the researcher collected data personally and also with the help research assistant. The research assistants were briefed about the data collection procedure. The 
respondent were faculty members of the universities and well aware from the research procedure. Meanwhile, the respondent of category three (students) were briefed by the researcher about how to respondent to different statements.

\section{Validity and Reliability}

Researcher consulted experts throughout the questionnaire development and modification of the items. After modification of the items the reliability coefficient was calculated for each questionnaire. For academic heads it was 0.872 , similarly for academia and students questionnaires were 0.775 and 0.899 .

\section{Results}

Job stress was independent variable whereas performance was dependent variable. Researcher calculated three types of analysis for the job stress of academia. Univariate analysis was used for the individual analysis of the all three categories of the respondents. The student respondents were used to measure the performance.

\section{Stress Levels of Academia}

The level and percentage were determined on the mean sample. The mean values on five point Likert scale was interpreted. According to Awino (2008) in finding job stress of university teacher and their levels as:

Table 3

Stress Levels of Academic heads and Academia

\begin{tabular}{lllll}
\hline Levels of stress & $\begin{array}{l}\text { Academia Heads } \\
(\mathrm{N}=242)\end{array}$ & $\begin{array}{l}\text { Academia } \\
(\mathrm{N}=422)\end{array}$ & $\begin{array}{l}\text { Mean } \\
\text { Range }\end{array}$ & Score \\
\hline Mild Stress & $79(33 \%)$ & $130(31 \%)$ & $1.00-2.50$ & \\
Moderate stress & $136(56 \%)$ & $228(54 \%)$ & $2.51-3.50$ & \\
High Stress & $27(11 \%)$ & $64(15 \%)$ & $3.51-5.00$ & \\
\hline
\end{tabular}

This table portrays levels of stress of academia and their heads. It was found that $33 \%$ of the academia heads and $31 \%$ of the academia has mild levels of stress. Whereas, 565 of academia heads and 545 of the academia has moderate level of stress. Furthermore, $11 \%$ of the academia heads and Table no 3 portrays levels of stress, $33 \%$ have mild, 
$56 \%$ moderate and $11 \%$ have high level of stress. These finding revealed that university academia has moderate level of stress.

\section{Influence of Job Stress Indicators on Academia and their Heads Performance}

Therefore, in order to observe the influence of explanatory variable on job stress of academia on their performance, multiple linear regression analysis was applied on academic heads and academia. The $\mathrm{R}^{2}=.46$ which indicates the Goodness of fit test of the model of heads performance in their job. It means that forty six percent of the variation is explained by the explanatory variables in their job performance. Whereas, the $F$ value 26.388 is highly significant .000 which means that variables are highly significant. It means at least one of the explanatory variable in the below model has the significant influence on the dependent variable. Furthermore, $\mathrm{R}^{2}=.63$ also indicates the Goodness of the fit test of the model of academia and $\mathrm{F}$ value 23.39 is highly significant which means at least one of the explanatory variable in the model II of academia has significant influence on the dependent variable.

Table 4

Influence of Various Stress Indicators on Performance of Academic Heads

\begin{tabular}{|c|c|c|c|c|c|c|}
\hline \multicolumn{7}{|c|}{ Coefficients } \\
\hline \multirow{2}{*}{\multicolumn{2}{|c|}{ Model Indicator }} & \multicolumn{2}{|c|}{$\begin{array}{l}\text { Unstandardized } \\
\text { Coefficients }\end{array}$} & \multicolumn{3}{|l|}{$\begin{array}{l}\text { Standardized } \\
\text { Coefficients }\end{array}$} \\
\hline & & $\mathrm{B}$ & Std. Error & Beta & $\mathrm{t}$ & P. Value \\
\hline 1 & Constant) & 3.869 & .578 & & 6.693 & 0.000 \\
\hline & $\begin{array}{l}\text { Autonomy in Work( } \\
\text { AW) }\end{array}$ & .461 & .234 & .197 & 1.970 & 0.005 \\
\hline & Quality of Work(QW) & .325 & .214 & .143 & 1.516 & 0.006 \\
\hline & Glexibility in Work(FW) & .286 & .147 & -.057 & 2.475 & 0.007 \\
\hline & $\begin{array}{l}\text { Organizational } \\
\text { Behavior(OB) }\end{array}$ & .133 & .141 & .069 & 3.33 & 0.000 \\
\hline & Financial Benefits( FB) & .152 & .155 & -.037 & -2.772 & 0.003 \\
\hline & $\begin{array}{l}\text { Social Interaction at } \\
\text { Work(SIW) }\end{array}$ & .147 & .203 & -.084 & -1.97 & 0.040 \\
\hline & Provision of Privacy(PP) & .413 & .173 & .286 & 2.394 & 0.017 \\
\hline
\end{tabular}




\begin{tabular}{llllll}
\hline $\begin{array}{l}\text { Communication Channel } \\
\text { at Work(CCW) }\end{array}$ & .354 & .143 & .303 & 2.478 & 0.014 \\
\hline $\begin{array}{l}\text { Working } \\
\text { Conditions(WC) }\end{array}$ & .412 & .155 & -.026 & -2.260 & 0.024 \\
\hline Furniture (F) & .212 & .134 & -.015 & -3.123 & 0.042 \\
\hline Equipment Facility(EF) & .228 & .164 & -.136 & -2.396 & 0.017 \\
\hline Space Organization(SO) & .222 & .137 & -.081 & -1.99 & 0.041 \\
\hline Personal Space(PS) & .150 & .149 & -.111 & -2.006 & 0.035 \\
\hline Individual Control(IC) & .176 & .154 & .060 & 3.049 & 0.002 \\
\hline Information Load(IL) & .428 & .122 & -.372 & -3.501 & 0.000 \\
\hline Energy Drain(ED) & .230 & .172 & .186 & 2.186 & 0.031 \\
\hline Adjusted $\mathrm{R}^{2}=0.46$ & & & $\mathrm{~F}=26.38$, Sig, at $\mathrm{P}<0.05$
\end{tabular}

The above multiple regression analysis indicates the results of job stress and performance. In the above said model the performance was dependent variable whereas job stress was independent variable. In the above table first column present the significant variables. The second column of this table shows the values of regression coefficient (B). Every $B$ values indicate the change in dependent variable with one unit change in explanatory variable (mentioned column one). Third column indicates standardized error of estimated regression coefficients. A fourth column of this table indicates standardized coefficients of each independent variable. The greater value of the standardized coefficient shows greater influence and smaller shows less influence on the explanatory variable. The fifth column shows the static $t$ values and the last columns show the $\mathrm{P}$ values.

In academic head model the $P$ values of all variables were less than the 0.05 which mean all have significant. This means all the values dimensions of the job stress taken in this study influence on the performance of academia and their heads. 
Table 5

Influence of Various Stress Indicators on Performance of Academia

\begin{tabular}{llllll}
\hline Coefficients & \multicolumn{3}{l}{ Standardized } \\
\hline
\end{tabular}

In this table the $\mathrm{p}$ values for all the dimension of job stress as taken by the researcher as job stress indicators for this study were highly significant as $\mathrm{P}$ of all less than 0.05 . It is also mentioned here that autonomy of work, quality of work, flexibility of work, organizational behaviors, and other variables as discussed above.

It was revealed from the results of above table 5 and 4 that academic heads and academia, that heads have more freedom, autonomy of work, flexibility of work, and equipment facility. Whereas, the faculty have 
less facilities in this regards their levels of stress was higher than of the academic heads.

\section{Conclusion}

It was concluded from the results that, autonomy of work, quality of work and flexibility of work were the indicator of job stress of academia. Increase in these factors will reduce the job stress of academia and their heads and which will definitely increase their performance and vice versa. Whereas, organizational behavior, financial benefits, social interaction, provision of privacy and communication channel at work place were also job stress indicators of the academia working in public sector universities of Punjab. Positive and smooth career promotion, enhancements in financial benefits, supportive and good working environment will motive the academia toward their work. These factors will reduce the job stress of academia and it will increase their performance and vice versa.

Furthermore, the working condition, office facilities and space in organization were also job stress indicators of the academia. A facilitation regarding these factor positively effect on the reduction of their job stress. It will definitely effect on their performance in their academic work. It was also revealed from the results that Individual control, information overload and personal space were also indicators of job stress of academia working in public sector universities of Punjab. A positive measure regarding these factors will reduce their stress. These stress reduction will enhance their performance. The results pointed out that academia and their heads both have moderate levels of stress. Whereas, the academia has less freedom autonomy, organizational space and equipments facility as compared to their heads in public sector universities of Punjab. The overall results show that job stress of academia in public sector universities of Punjab negatively effects on their performance.

\section{Discussion}

The present study has explored the job stress of academia and its effect on their performance in public sector universities in Punjab. The study was planned in nine regions of the Punjab namely Rawalpindi, Dera Ghazi Khan, Multan, Faisalabad, Rawalpindi, Lahore, Gujranwala, Sahiwal and Sargodha. One public sector university from each region with a largest population was selected. Dera Ghazi Khan and Sahiwal 
regions were excluded from the study for having no public sector university. The seven universities representing each region were the population of the study. These universities were, PU from Lahore, BZU from Multan, PMAS-arid from Rawalpindi, UOS form Sargodha, UOG from Gujrat, IUB from Bahawalpur and GCU from Faisalabad.

The findings of the multivariate analysis also indicted that, the indicators of job stress influence the performance of the academia. The findings show these stress indicators autonomy, quality of work, flexibility of work, organizational behavior, financial benefits, social interaction at work, provision of privacy, communication channel at work, official furniture, equipment facility, space organization, personal space, individual control, information load and energy drain influence the performance of academia. The analysis of these indicators pointed out there sub items, decision making, role clarity, teaching of new course, lack of participation in decision making, internal conflicts and HEC criteria for promotion were also sources and causes of stress which influence on their performance. It was also concluded from the findings that lack of opportunity for future preparation, deadlines, teaching of new course, work load, unjust treatment for carrier promotion, pay benefits, funding for research, relation at workplace, also causes stress that affect their performance.

The result of data also concluded that lack of coordination, taking new initiative, office space, work place environment, official furniture, poor rapport, personal responsibility, discrimination by boss; long working hours, publication requirements, rewards and recognition, and unbiased performance evaluation are the sources of stress for academia. On the basis of these findings of present study it can be concluded that the phenomena of job stress is prevailing in our academia working in public sector universities of Punjab. It was also apparent from the results that academia stress is multiple factor construct, and these entire factors are associated with each other's. It is also found that academia stress negatively effect on the performance of academia. It was also found that demographic variables also lead towards that phenomenon.

\section{Recommendations}

The university as an organization may conduct need assessment for academia assistant program. It was also recommended that management of university needs to explore the causes of the dissatisfaction of academia within the working environment. For this purpose, a seminar or workshop on the matter may be conducted. The public sector university 
heads (Deans and Chair) may assess the levels of their academia knowledge and skills and whether they will be able to meet their deadlines. Work should be assigned as per their expertise and willingness. Furthermore, time management training may be given to academia on a continuous basis that will help to meet the deadlines of their tasks. It was also recommended from the conclusion that, academic heads may assign tasks to their academia in consultation with them as per their area of specializations. It is recommended that academic heads may conduct academia audit which will facilitate them for better utilization of their academia. Academia head should invite academia, who thinks that they are being given job that are in contradiction with each other, and clarify their roles. 


\section{References}

Ahmadi, K. (2007). Stress and Job Satisfaction of the employee. Journal of Social Sciences and Education. (4).

Ali, S. (2008). Faculty Development Program for Universities of Pakistan: The Need to Develop a Model. (Unpublished Doctoral Thesis). Lahore: University of the Punjab.

Paul, R., \& Lawrence, J. (2002). Faculty at Work: Motivation, Expectation, and Satisfaction. Baltimore, MD: The Johns Hopkins University Press.

Borko, H. (2004). Professional Development and Teacher Learning: Mapping the Terrain. Educational Researcher, 33(8), 3-15.

Braun, H. J. (2005). Using student progress to evaluate teachers: A primer on value-added models. Princeton, NJ: Educational Testing Service. Available online at: http://www.ets.org/research/pic.

Calin, A. L. (2006). Is Subject Matter Knowledge Affected by Experience? The Case of Composition of Functions: Canada: Simon Fraser University.

Campbell, R. L, \& Svenson, L.W. (1992). Perceived level of stress among University undergraduate students in Edmonton, Canada. Percept Motor Skills, 75(2), 552-554

Cresswell, J. W. (2003) .Research Design. Qualitative, quantitate and mixed method approach. London: Sage Publications Inc.

Daniel, J. (2003). Mega Universities and Knowledge Media. London: Koganpage Ltd.

Darling-Hammond, L. (1999). Doing what Matters Most, Inverting in quality teaching. New York: National Commission on Teaching and America's Future. 
Goswami, T.G.(2015). Job Stress and its Effect on Employee Performance in Banking Sector. Indian Journal of Commerce \& Management Studies.6 (2), 51-56.

Higher Education Commission of Pakistan (2007). Annual Report, Islamabad: HEC.

Judeh M. (2011). Role ambiguity and role conflict as mediators of the relationship between socialization and organizational commitment. International Business Research. 4(1), 171-182.

Kotteeswari, M. \& Tameem, S. S. (2014). Job Stress and Its Impact on Employees' Performance: A Study With Reference to Employees Working in BPOS. International Journal of Business and Administration Research Review, 2(4); 18-25.

Mirella, H. G. (2005). Stress in the Workplace. Management Magazine, 7 (August): 19-21.

Mohanty Institute of occupational safety and Health. (2000). Job stress,

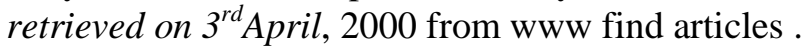

Mohanty, J. (2000). Current Trends in Higher Education. New Dehli: Deep and Deep Publications.

Radcliff, C. \& Lester, H. (2003). Perceived stress during undergraduate medical training: A Qualitative study Medical education. Wiley Online Library.

Raza, S. A., Majid, Z., Zia, A. (2010). Perceptions of Pakistani University Students about Roles of Academics Engaged in Imparting Development Skills: Implications for Faculty Development. Bulletin of Education \& Research. 32(2), 75-91.

Raza, S.A. \& Naqvi, S. A. (2011). Quality of Pakistani University Graduates as Perceived by Employers: Implication for Faculty Development. Journal of Quality and Technology Management, 7 (1), 57-72. 
Rubina, H. (2004). Teacher Job Stress, Efficacy and performance. QAU (Unpublished PhD thesis). QAU, Islamabad, Pakistan.

Verma, R. (2008). Psychology of teachers. New Delhi: Anmol publication. Pvt. LTD.

\section{Citation of this Article:}

Chaudhry, M. A., \& Niazi, H. K. (2017). Job stress of academia and its effect on their performance in public sector universities of Punjab.

Pakistan Journal of Education, 34(2), 101-118.

$\begin{array}{ll}\text { Received on: February } & 29,2016 \\ \text { Revised on: August } & 29,2017 \\ \text { Accepted on: } \text { October } & 19,2017\end{array}$

